\author{
近藤 義宏* ·松村 智秀*2. 行方 二郎 $*$ \\ 山口 泰広 $* 3$. 田中 勝 $* 3$. 半谷 文雄 $* 3$
}

\title{
Degradation of SUS 304 by High Temperature Exposure and Recovering Heat-treatment Effect
}

\author{
Yoshihiro Kondo, Tomohide Matsumura, Jirou Namekata, \\ Yasuhiro YamaguchI, Masaru TANAKA and Fumio HaNGAI
}

\section{Synopsis :}

The degradation of mechanical properties of SUS 304 during high temperature exposure were investigated by comparing as solution treated specimen with the specimen serviced for $120000 \mathrm{~h}$ in an ethylene plant. Additionally, a restoration of mechanical properties was examined by applying the re-solution treatment to the specimen serviced for the prolonged time, and the microstructural change which affected the degradation was discussed. There was little difference in short time tensile properties among the above three different specimens, except for rupture ductility. More than half decreases in a creep resistance, a creep rupture strength and an impact property were detected in serviced specimen. All these properties, however, could substantially be restored by the application of re-solution treatment to the serviced specimen. The degradation of these mechanical properties during high temperature service were mainly caused by the intergranular precipitation of a sigma phase, and the decrease in density of carbide precipitates, accompanied with the intergranular precipitation of a sigma phase.

Key words: heat treatment; stainless steel; steel for elevated temperature service; precipitation; creep; strength; mechanical testing.

\section{1. 緒 \\ 言}

高温構造部材の設計基準の一つとして $10^{5} \mathrm{~h}$ クリープ 破断強さが用いられてきたが，すでに $10^{5} \mathrm{~h}$ を超え，な お稼動中の高温機器の数がわが国においては急増してい る. そこで, 長時間使用されたこれら高温構造部材の更 新時期を決定する目的で，余命推定法や損傷評価技術の 確立が急がれている。また，高温使用に起因した材料強 度の低下量を定量的に把握しょうとする基礎的な研究 も, 一方ではいくつか行われてきている ${ }^{1) \sim 9)}$. 高温使用 により生じる材料強度の低下に対しては, 従来, 割れや 空泡の発生及び伝播に起因した機械的損傷 ${ }^{12)}$ あるいは 炭化物の粗大化のような試料全体で均一に生じる組織変 化に基づいた材質劣化 ${ }^{3) \sim 9)}$ がおもなる原因として考えら れてきた。 ところが，木村らは $\mathrm{Cr}-\mathrm{Mo}-\mathrm{V}$ 鋼のような低
合金鋼においては, これら機械的損傷や均一な組織変化 が強度低下を招くのではなく，旧オーステナイト粒界に 沿つたフェライトの形成という不均一な組織変化に基ゔ いた材質劣化が強度低下の要因であることを指摘し た 10) 12). しかし,オーステナイト系耐熱鋼の高温クリー プにおける強度低下については，これまで粒界における 割れの発生及び伝播のような機械的損傷と関連づけられ てきた。また，耐熱鋼を高温で長時間使用した場合，強 度低下だけではなく，破断延性の低下のような脆化現象 が生じることも良く知られている6(9)13) 17). この場合 も，炭化物あるいは $\sigma$ 相等の金属間化合物の粒界におけ る塊状析出と粒界割れの誘発との関連が検討される場合 が多い69913). しかし，粒界におけるそのような組織変 化の, 短時間の引張特性あるいは高温クリープ抵抗に及 ほす効果はほとんど検討されていない.したがつて, 機

昭和 58 年 10 月本会講演大会にて発表 昭和 62 年 9 月 4 日受付 (Received Sep. 4, 1987)

* 防衛大学校機械工学教室 工博 (Department of Mechanical Engineering, The National Defense Academy, 1-10-20 Hashirimizu Yokosuka 239)

*2 防衛大学校機械工学教室 (Department of Mechanical Engineering, The National Defense Academy)

*3 ニダック(株)技術部 (Engineering department, Nidak corp.) 
械的損傷を受けることがなく，材質劣化のみが生ずると 考えられる単純時効材を取り上げ，高温使用による強度 低下と組織変化との関連をまず検討する必要がある。 ま た，材質劣化により強度低下を生じた材料の組織を再熱 処理によつて初期の組織,例えば固溶化組織にもどせば， 機械的性質も初期の值にまで回復することが予想され $3^{18) 19}$. ᄂかし，再熱処理による高温長時間使用材の 機械的性質の変化を SUS 304 などの般造材について倹 討した報告は少ない.

そこで本研究においては耐熱鋼としては，比較的使用 温度が高いものの，単純時効とみなせるほど低い応力条 件下に扔いて約 $1.2 \times 10^{5} \mathrm{~h}$ 使用された SUS 304 につい て材質少化の量を未使用材と比較することにより調べ る.また，この長時間使用材に再度，固溶化熱処理を施 すと材質劣化がほぼ完全に回復するかどうかを調査し て,このような長時間使用材の材質劣化を決定する組織 因子を検討する

\section{2. 実 験 方 法}

供試鋼はエチレン製造装置のナフサ分解炉内において 比較的温度の高い対流部で約 $1.2 \times 10^{5} \mathrm{~h}$ 使用された SUS 304 （以後，使用材と呼ぶ）であり，稼動温度は $750^{\circ} \mathrm{C}$, 内压 $2.0 \mathrm{kgf} / \mathrm{cm}^{2}$ (応力水準から判断して単純時 效材とみなせる) と推定される. また，比較材として， Table 1 に示すように，使用材とほぼ同じ化学組成をも つ市販の SUS 304 (以後, 未使用材と呼ぶ）も準備した。 これについては $1100^{\circ} \mathrm{C} て ゙ ~ 1 \mathrm{~h}$ の固溶化熱処理を施し， 結晶粒径を使用材と同じ約 $100 \mu \mathrm{m}$ に調整した。ささらに， 使用材に $1000^{\circ} \mathrm{C}, 30 \mathrm{~h}$ の再固溶化熱処理を施した試料 （以後，再固溶化材と呼ぶ）も準備した. なお，再固溶 化材の結晶粒径も約 $100 \mu \mathrm{m}$ である．短時間引張試験及 びクリープ試験にはいずれも平行部径 $6.0 \mathrm{~mm}$, 標点距 離 $30 \mathrm{~mm}$ の試験片を使用し，前者については室温及び $750^{\circ} \mathrm{C}$ に打いて，また，後者については $750^{\circ} \mathrm{C}$ の一温 度域で行つた。衝撃試験には JIS 4 号 $2 \mathrm{~mm} \mathrm{~V}$ ノッチ サブサイズ $(5 \times 10 \times 55$ mm) の試験片を準備し，計装化

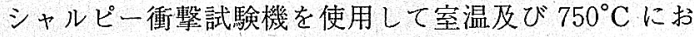
いて行つた.

組織観察には光顕，走査電顕及び透過電影を用いた。

Table 1. Chemical composition of steels studied (wt\%).

\begin{tabular}{c|ccccccc}
\hline Steel & $\mathrm{C}$ & $\mathrm{Si}$ & $\mathrm{Mn}$ & $\mathrm{P}$ & $\mathrm{S}$ & $\mathrm{Ni}$ & $\mathrm{Cr}$ \\
\hline As used & 0.06 & 0.55 & 1.57 & 0.030 & 0.014 & 9.54 & 18.50 \\
Virgin & 0.08 & 0.60 & 1.29 & 0.028 & 0.005 & 9.24 & 18.70 \\
\hline
\end{tabular}

また，析出相の同定は電解抽出残椬の X 線回折及び透過 電顕の制限視野回折により行つたが，STEMタイプの 分析電顕も併用した。

\section{3. 実 験 結 果}

\section{$3 \cdot 1$ 使用材の組綗}

Photo. 1 に使用材，未使用材及び再固溶化材の光顕 組織を示す。なお，使用材（a）については $1 \mathrm{~N} の ~ \mathrm{KOH}$ による電解腐食を行つた. 使用材の粒界においては黄色 を呈した塊状の析出相が，また粒内でも青色を呈した粒 状相に加えて黄色を呈した針状相が認められた。これら のカラー腐食より，黄色を呈した粒界の塊状相及び粒内 の針状相は $\sigma$ 相，また青色を呈した粒内の微細な粒状相 は炭化物と推定される ${ }^{20)}$. 一方，未使用材 ( b ) はほほ 完全な固溶化組織を示し，結晶粒径は使用材と同じ約
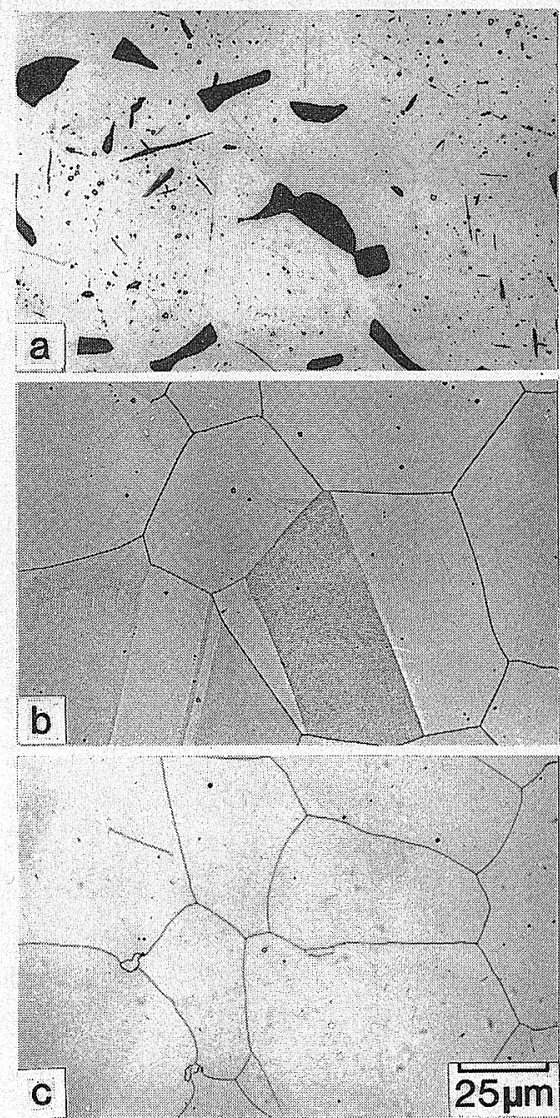

a : As used b : Virgin $\quad c:$ Re-solution treated Photo. 1. Optical microstructures of as used, virgin and re-solution treated steels. 

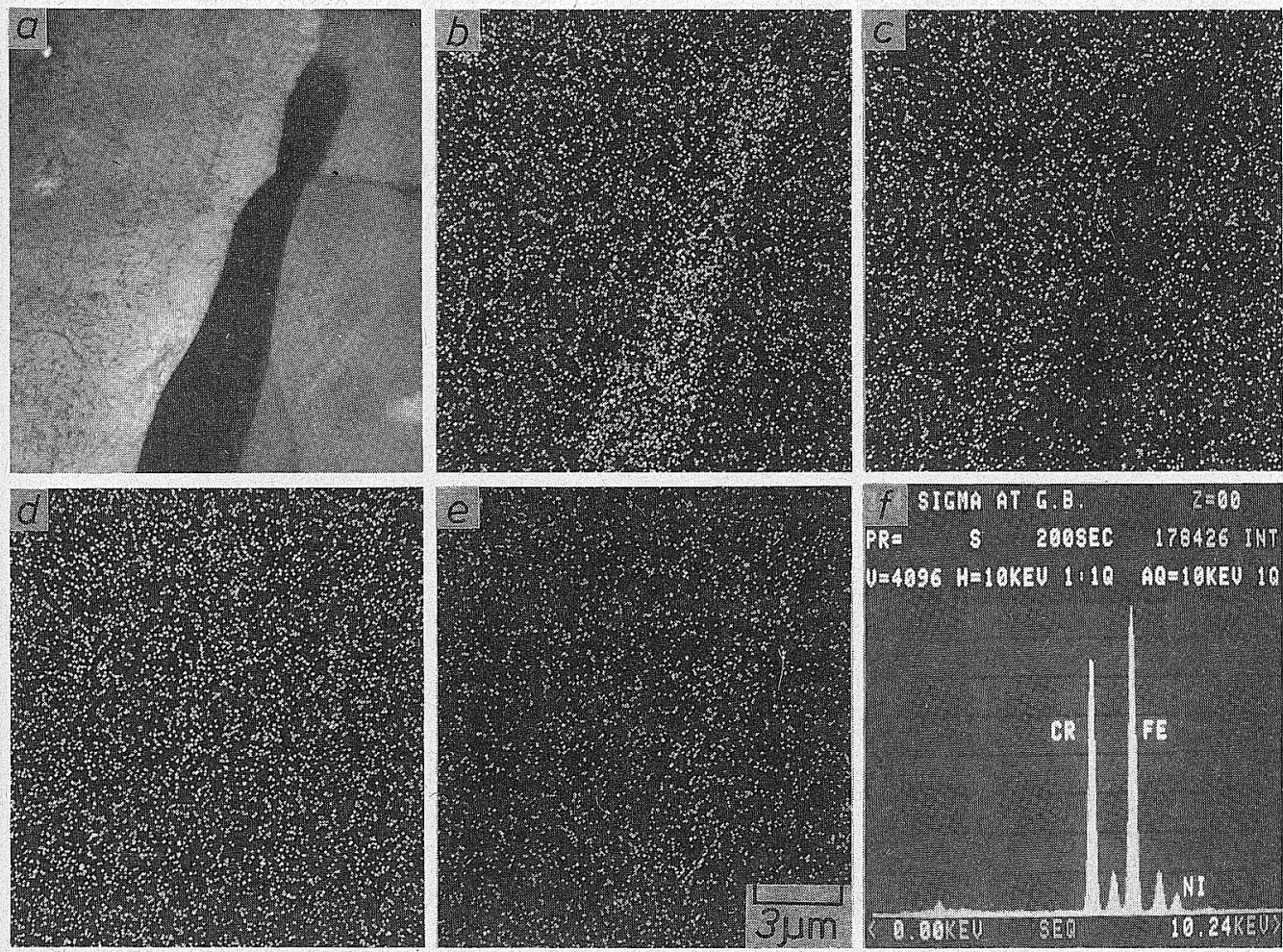

a : STEM image $\quad b: \mathrm{Cr}_{-} \mathrm{K}_{\alpha} \quad c: \mathrm{Ni}-\mathrm{K}_{\alpha} \quad \mathrm{d}: \mathrm{Fe}-\mathrm{K}_{\alpha} \quad$ e : $\mathrm{Si}_{-} \mathrm{K}_{\alpha} \quad$ f : EDX spectrum

Photo. 2. STEM image, $\mathrm{X}$-ray mapping images $\left(\mathrm{Cr}-\mathrm{K}_{\alpha}, \mathrm{Ni}-\mathrm{K}_{\alpha}, \mathrm{Fe}-\mathrm{K}_{\alpha}, \mathrm{Si}-\mathrm{K}_{\alpha}\right)$ and EDX spectrum of as used steel.

Table 2. Comparison of X-ray diffraction data of precipitates extracted from as used steel.

\begin{tabular}{|c|c|c|c|c|c|}
\hline \multicolumn{2}{|c|}{ Experimental value } & \multicolumn{2}{|c|}{$\mathrm{M}_{23} \mathrm{C}_{6} *$} & \multicolumn{2}{|c|}{$\sigma$-phase ${ }^{* *}$} \\
\hline$d_{o b s}$ & $I_{\text {obs. }}$ & $d_{\mathrm{M}_{23} \mathrm{C}_{6}}$ & $I / I_{0}$ & $d_{\sigma}$ & $I / I_{0}$ \\
\hline 2.656 & 115 & 2.66 & 30 & - & - \\
\hline 2.375 & 508 & 2.37 & 50 & - & - \\
\hline 2.169 & 606 & 2.17 & 50 & - & - \\
\hline 2.125 & 371 & - & - & 2.128 & 100 \\
\hline 2.067 & 125 & - & $\overline{10 n}$ & 2.063 & 80 \\
\hline 2.045 & 2138 & 2.05 & 100 & & - \\
\hline 2.023 & 260 & - & - & $\begin{array}{l}2.015 \\
1.964\end{array}$ & $\begin{array}{l}60 \\
80\end{array}$ \\
\hline $\begin{array}{l}1.972 \\
1.927\end{array}$ & $\begin{array}{r}535 \\
384\end{array}$ & - & - & $\begin{array}{l}1.964 \\
1.928\end{array}$ & $\begin{array}{r}80 \\
100\end{array}$ \\
\hline 1.879 & $\begin{array}{l}504 \\
642\end{array}$ & 1.88 & 50 & $\begin{array}{l}1.960 \\
1.877\end{array}$ & $\begin{array}{r}100 \\
80\end{array}$ \\
\hline 1.837 & 114 & $\overline{80}$ & $\overline{50}$ & 1.830 & 10 \\
\hline $\begin{array}{l}1.797 \\
1.772\end{array}$ & $\begin{array}{l}531 \\
293\end{array}$ & $\begin{array}{l}1.80 \\
1.78\end{array}$ & $\begin{array}{l}50 \\
40\end{array}$ & 1.755 & 10 \\
\hline$\overline{602}$ & $\overline{189}$ & 1.63 & $\begin{array}{r}5 \\
30\end{array}$ & - & - \\
\hline & & & & & \\
\hline
\end{tabular}

* : Representative JCPDS Card, 5-0708

** : Representative JCPDS Card, 14-0407

$100 \mu \mathrm{m}$ に調整されている. さらに，再固溶化材 (c)に おいては，ごく一部の粒界で $\delta$ フェライト相が観察さ れたが，粒内において析出相は確認されず，ほぼ完全な 固溶化組織を示している. また，再固溶化熱処理による
オーステナイト結晶粒の成長はほとんどない.

使用材から電解抽出した残渣のX線回折結果を Table 2 に示す. JCPDS カード21)22) での面閒隔及び相対強度 との比較より，使用材に析出した相は $\sigma$ 相及び $\mathrm{M}_{23} \mathrm{C}_{6}$ と同定された。粒界に析出した塊状相の STEM 像, $\mathrm{Cr}, \mathrm{Ni}, \mathrm{Fe}$ 及び $\mathrm{Si}$ の特性 X 線像及び $\mathrm{EDX}$ スペクトル をPhoto. 2 に示す.母相に比べ,塊状相の Cr 量は高く， また, Si もわずかに濃縮している．しかし，Fe 量には ほとんど差がなく，Ni 量は著しく低い，粒内の針状相 及び粒状相についても，特性X線像を調べた。 その結果， 前者は粒界の塊状相とほぼ同様の組成を示し，後者は $\mathrm{Cr}$ 量が著しく高く, Ni 及び Fe 量は著しく低いことが 判明した。さらに，粒界の塊状相について EDXによる 組成分析を行つた結果, $\mathrm{Cr} と \mathrm{Fe}$ がほほ同量 $(\mathrm{Cr}: 42$ at $\%, \mathrm{Fe}: 52$ at\%) であり， $\sigma$ 相の組成 ${ }^{23)-25)}$ とほぼ一 致していた．したがつて，粒界の塊状及び粒内の針状相 は $\sigma$ 相であり，粒内の粒状相は $\mathrm{M}_{23} \mathrm{C}_{6}$ であると判定さ れる. 


\section{$3 \cdot 2$ 高温長時間使用による機械的性質の变化とこれに 及ぼす再熱処理の影糡}

$3 \cdot 2 \cdot 1$ 短時間引張特性の変化

室温及び $750^{\circ} \mathrm{C}$ で行つた SUS 304 の短時間引張試験 結果を Table 3 に示す. 使用材及び未使用材とも $0.2 \%$ 耐力は室温で約 $25 \mathrm{kgf} / \mathrm{mm}^{2}, 750^{\circ} \mathrm{C}$ においては約 11 $\mathrm{kgf} / \mathrm{mm}^{2}$ であり，また引張強さは室温で約 $66 \mathrm{kgf} / \mathrm{mm}^{2}$, $750^{\circ} \mathrm{C}$ においては約 $21 \mathrm{kgf} / \mathrm{mm}^{2}$ であり, 高温長時間の 使用による低下はほとんどない。一方，使用材の破断伸 びは室温の試験において，未使用材に比べ低い值を示す

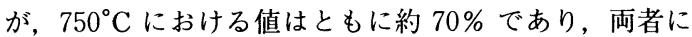
差違は生じない。また, 再固溶化材の $0.2 \%$ 耐力, 引 張強さは室温及び $750^{\circ} \mathrm{C}$ のいずれの温度域においても 使用材及び未使用材での值とほほ同じである. 一方, 使 用材の室温における破断伸びの低下は再固溶化熱処理を

Table 3. Tensile properties of as used and virgin steels at room temperature and $750^{\circ} \mathrm{C}$.

\begin{tabular}{l|c|c|c|c}
\hline Temperature & Steel & $\begin{array}{c}0.2 \% \text { proof } \\
\text { stress } \\
\left(\mathbf{k g f} / \mathrm{mm}^{2}\right)\end{array}$ & $\begin{array}{c}\text { Tensile } \\
\text { strength } \\
\left(\mathbf{k g f} / \mathrm{mm}^{2}\right)\end{array}$ & $\begin{array}{c}\text { Elongation } \\
(\%)\end{array}$ \\
\hline $\begin{array}{l}\text { Room } \\
\text { temperature }\end{array}$ & $\begin{array}{c}\text { As used } \\
\text { Virgin }\end{array}$ & 24.7 & 65.3 & 54.7 \\
\hline $750^{\circ} \mathrm{C}$ & $\begin{array}{c}\text { As used } \\
\text { Virgin }\end{array}$ & 10.3 & 67.7 & 83.9 \\
\hline
\end{tabular}

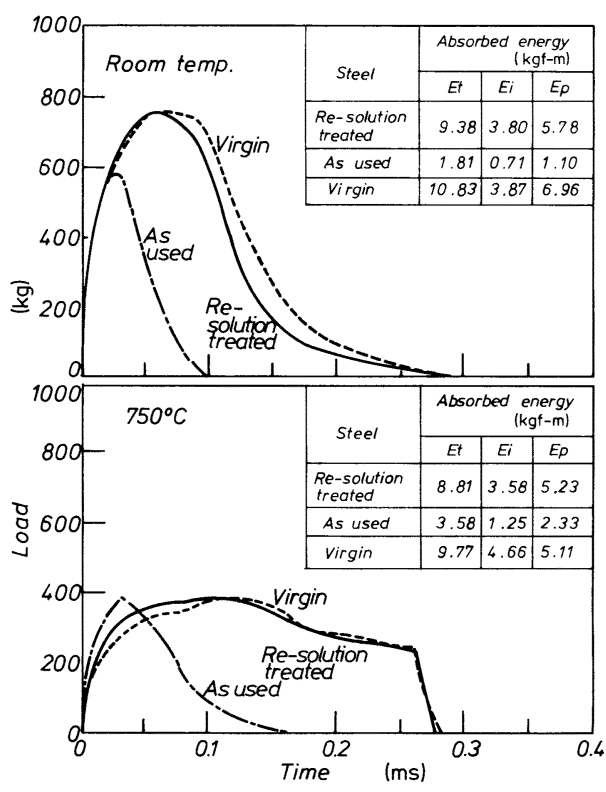

Fig. 1. Time-load curves and impact properties of as used, virgin and re-solution treated steels Charpy impact tested at room temperature and $750^{\circ} \mathrm{C}$.
施すことにより，未使用材の値にまで回復する.

\section{$3 \cdot 2 \cdot 2$ 衝撃特性の変化}

計装化シャルピー衝撃試験機を用いて求めた室温及び $750^{\circ} \mathrm{C}$ での荷重-時間曲線を Fig. 1 に示す.なお，全吸 収エネルギー, $E t$, 最大荷重前のエネルギー, $E i$, 及び 最大荷重後のエネルギー, $E p$, , 值についても同図に併 せて示した．最大荷重については，使用材の值は未使用

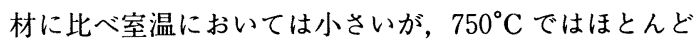
差はない.また, 最大荷重を示した後の荷重の減少量は, いずれの試験温度においても未使用材に比べ使用材で大 きい. ところが，使用材に再固溶化熱処理を施すと，い

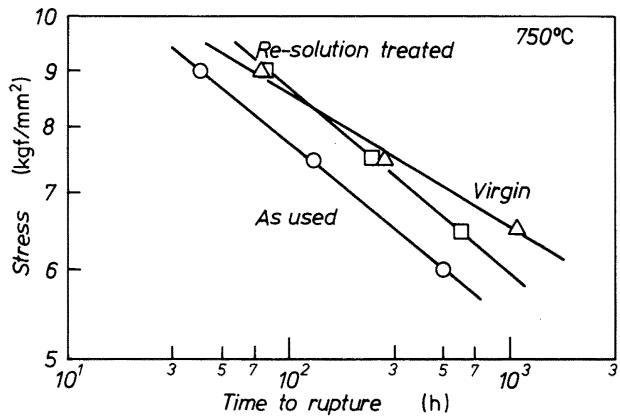

Fig. 2 Stress-time to rupture curves of as used, virgin and re-solution treated steels crept at $750^{\circ} \mathrm{C}$.

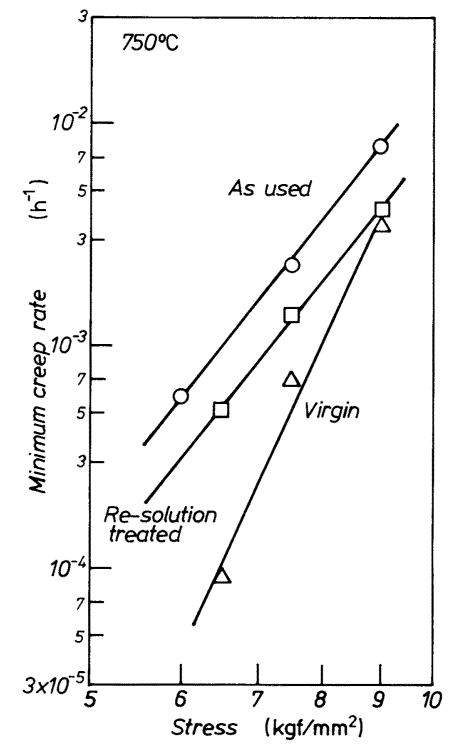

Fig. 3. Stress-minimum creep rate curves of as used, virgin and re-solution treated steels crept at $750^{\circ} \mathrm{C}$. 
ずれの試験温度に扔いても荷重-時間曲線は未使用材の ものとほぼ一致するようになる。

\section{$3 \cdot 2 \cdot 3$ クリープ特性の変化}

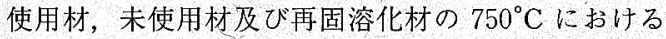
応力-破断時間曲線を Fig. 2 に示す. 使用材の破断時間 は未使用材の $1 / 3 \sim 1 / 5$ であり，低応力，長時間側に゙お いて未使用材に比べとくに短い．使用材に再固溶化熱処 理を施すと，高応力，短時間側の破断時間は未使用材の 值にまで回復するが，低応力，長時間側の值は未使用材 の値にまでは回復しない．

つぎ，使用材，未使用材及び再固溶化材の $750^{\circ} \mathrm{C}$ における応力ー最小クリープ速度曲線を Fig. 3 に示す。 使用材の最小クリープ速度は高応力側において，未使用 材の約 3 倍を゙あるが，応力が低下すると 10 倍を超える。 なお,最小クリープ速度の応力指数, $n$, は使用材で約 5 , 未使用材で約 8 であつた。ところが，使用材に再固溶化 熱処理を施すと，最小クリープ速度は高応力側において 未使用材の值にまで減少するが，低応力側では未使用材 の值までは減少せず，最小クリープ速度の応力指数も使 用材と同一の約 5 であつた。

\section{4. 考察}

\section{$4 \cdot 1$ 長時間使用材の短時間引張特性及び衝撃特性に及 ぼす組織の影響}

$750^{\circ} \mathrm{C}$ で約 $1.2 \times 10^{5} \mathrm{~h}$ 使用した SUS 304 の長時間使 用材は，炭化物あるいは $\sigma$ 相が析出し，それらが粗大化 した組織からなり， $\gamma$ 単相の未使用材の組織とは非常に 異なつていたが，短時間の引張強度については，両者の 差違はほとんどなかつた。

SUS 304 の固溶化材においては高温使用中に炭化物 が析出してここれによる析出分散強化が㗢くようになる. 炭化物による析出分散強化の量は，併せて生ずる固溶炭 素による強化量 ${ }^{26) 27)}$ の減少に比べ非常に大きいため, 高温加熱材の強度は固溶化材に比へ通常は高い.しかし， 固溶化材の $750^{\circ} \mathrm{C}$ における短時間引張試験に要する時 間は最長 $1 \mathrm{~h}$ 程度であり；非常に短く，短時間引張試験 中には炭化物による十分な析出分散強化は㗢かないと考 えられる. 一方, $750^{\circ} \mathrm{C}$ 時効材の短時間引張強度は炭化 物の析出がほば完了する $1000 \mathrm{~h}$ 以内で最大值を示し, $10^{5} \mathrm{~h}$ を超えた高温使用材においては，炭化物による析 出分散強化量は大きく低下しているとみなすことができ る. したがつて，使用材と未使用材の短時間引張特性， とくに強さに差が認められなかつた理由は，析出分散強 化がそれぞれにおいて十分には働いていなかつたためと 推論される.
一方, 衝撃吸収エネルギー及び室温の短時間引張試験 に扔ける破断伸びについては長時間使用材が未使用材に 比べより小さな值を示した。しかし，長時間使用材に再 固溶化熱処理を施すと,これらはともに未使用材の值に まで回復した. したがつて，高温長時間使用材で認めら れた衝撃值の低下あるいは短時間引張試験に掞ける破断 伸びの低下のような脆化現象は高温長時間使用中に形成 された組織に起因すると考えられる。未使用材，使用材 及び再固溶化材の室温に扔ける衝撃試験破面の反射電子 像を Photo. 3 に示す. 未使用材の破面 (Photo. 3a) は 延性破壊を表すディンプル模様を呈するが，使用材の破 面 (Photo. 3b) はへき開破壞を呈し，多数の割れを生 した塊状のの相が認められた。ところが，再固溶化材 (Photo. 3c) に扔いては未使用材と同様の延性破面を呈 した. 新谷らは数種の SUS 304 について $600 \sim 900^{\circ} \mathrm{C}$

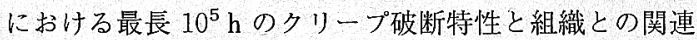

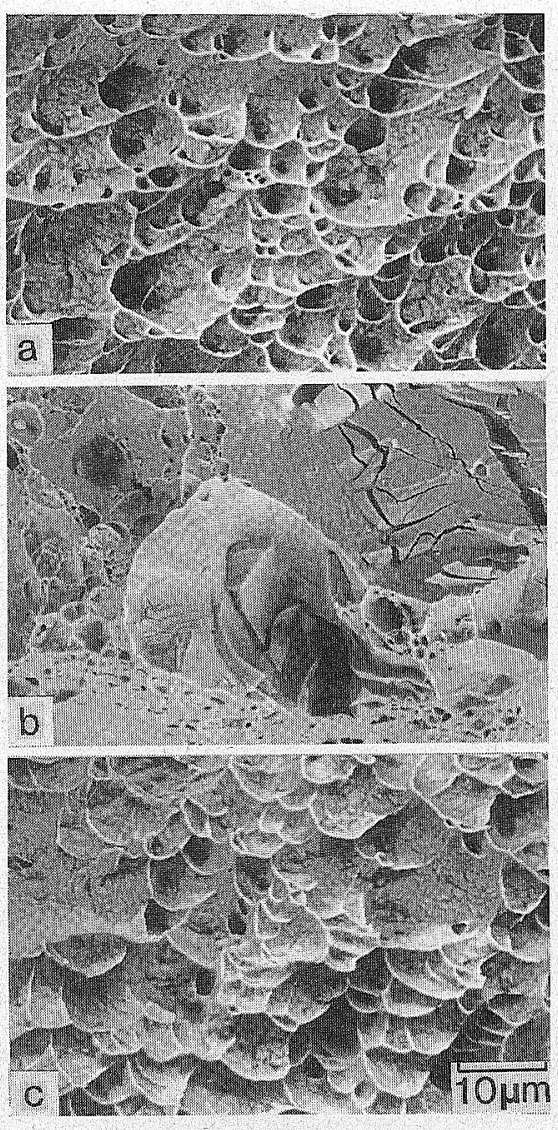

a : Virgin b : As used c : Re-solution treated

Photo. 3. Reflective electron fractgraphs of virgin, as used and re-solution treated steels. 
を調へ，一部の鋼種で認められる長時間側でのクリープ 破断強さの急激な低下は，粒界 $\sigma$ 相に接したAlN の析 出と，これに誘発された粒界割れの形成に起因すると推

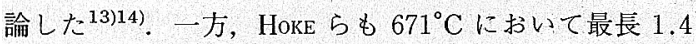
$\times 10^{4} \mathrm{~h}$ まで使用した SUS 304, 316, 321 及び 347 の延 性低下は $\sigma$ 相の析出及び炭化物の粗大化などの組織变化 に起因すると考えた ${ }^{9)}$. STOTER ${ }^{6)}$ 及び行俊ら ${ }^{15)}$-17) もこ れと同様の脆化現象が $10^{4} \mathrm{~h}$ を超えて使用された市販の 耐熱鋼に生し，それが前述のような組織変化，とくに塊 状 $\sigma$ 相の粒界析出と直接的に関連することを明らかにし ている.

塊状 $\sigma$ 相の粒界析出は, 粗大な形状に起因した幾何学 的な不均一性を増大させるため， $\sigma$ 相と $\gamma$ 素地での割れ の発生を容易にさせ，また伝播をも促進させると考えら れる.ここで, Fig. 1 に拈いて使用材の最大荷重後の 鞁性の著しい低下のパラメーターとして示した $E i$ を割 れの発生エネルギー, 一方，Ep 割れの伝播エネルギ - ${ }^{28)}$ とみなすと，使用材の $E i$ 及び $E p$ は未使用材にお ける值に比べ，いずれも室温では約 $1 / 6 に$ にまた， $750^{\circ} \mathrm{C}$ では約 $1 / 3$ に減少していた.このことから長時 間使用材では塊状 $\sigma$ 相の粒界析出に伴い, 割れの発生及 び伝播が容易になつたため衝撃吸収エネルギーの顕著な 低下を生じたと考えられる.また，これらの脆化現象が 歪み速度の高い短時間引張試験と衝撃試験において現

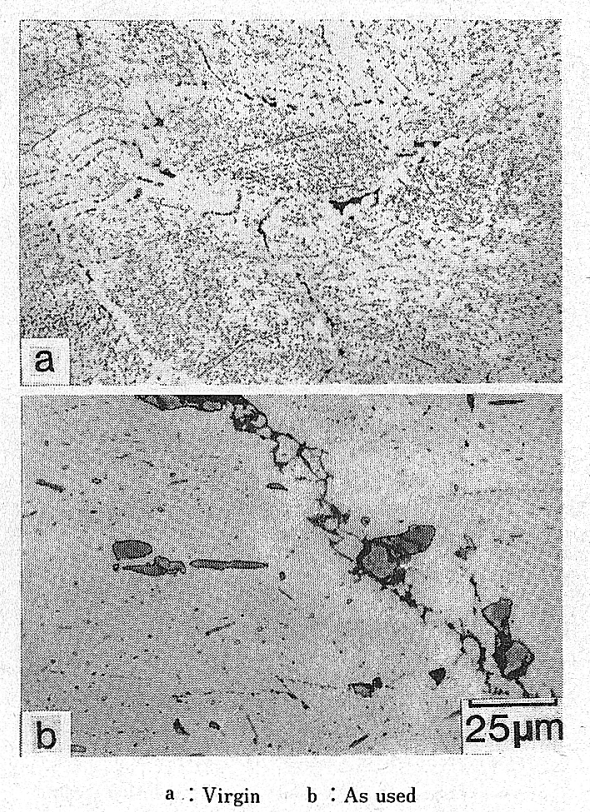

Photo. 4. Optical microstructures of virgin and as used steels crept at $750^{\circ} \mathrm{C}-7.5 \mathrm{kgf} / \mathrm{mm}^{2}$.
れ，歪み速度が低いクリープ試験においては生じなかっ たことからも粒界割れとの関連が推察できる.

\section{$4 \cdot 2$ 長時間使用材のクリープ抵抗の低下を招く組織因 子}

$750^{\circ} \mathrm{C}$, 応力 $7.5 \mathrm{kgf} / \mathrm{mm}^{2}$ においてクリープ破断した 未使用材及び使用材の破面近傍の光顕組織を Photo. 4 に示す. 未使用材 (Photo. 4a) の粒界には粒状相が，ま た，粒内においてはより微細な粒状相が均一に分散析出

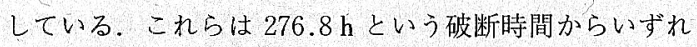
も $\mathrm{M}_{23} \mathrm{C}_{6}$ と推定される ${ }^{25)}$. しかし, 使用材 (Photo. 4b) では粒界上に塊状の $\sigma$ 相が，粒内には針状の $\sigma$ 相と粒状 の $\mathrm{M}_{23} \mathrm{C}_{6}$ が認められ, 塊状 $\sigma$ 相の周囲では炭化物はほ とんど観察されず, クリープ試験を行つても使用材の組 織にほとんど変化はない.

同一試料の透過電顕組織を Photo. 5 に示す. 未使用 材の破断材 (Photo. 5a) で観察された粒内炭化物は使用 材のもの (Photo. 5b) に比べかなり小さく, その析出 密度も非常に高い.このことから長時間使用材のクリー プ抵抗が未使用材に比べて半減あるいはそれ以下に低下 したのは，未使用材においてはクリープ中に炭化物が均 一微細に析出して，クリープ抵抗が非常に高くなるのに 対して，使用材では $\sigma$ 相や炭化物はすでに粗大化し，こ れらによる分散強化が十分には働かないこと及び塊状の $\sigma$ 相の周囲で炭化物の析出がほとんど無い, クリープ抵
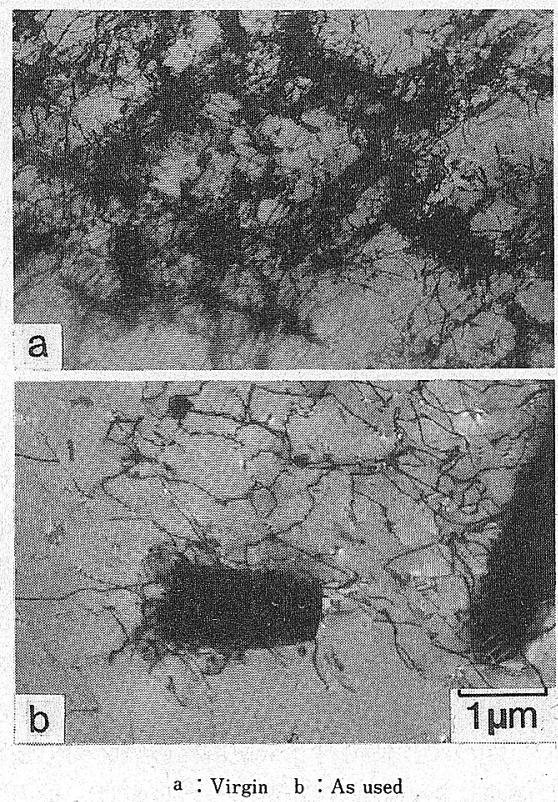

Photo. 5. Transmission electron micrographs of virgin and as used steels crept at $750^{\circ} \mathrm{C}-7.5$ $\mathrm{kgf} / \mathrm{mm}^{2}$. 


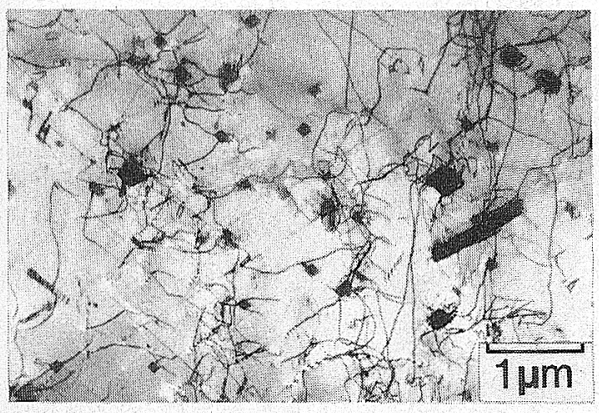

Photo. 6. Transmission electron micrograph of re-solution treated steel crept at $750^{\circ} \mathrm{C}-7.5$ $\mathrm{kgf} / \mathrm{mm}^{2}$.

抗が低い領域が形成されていることによると結論され る.

つぎに，使用材に再固溶化熱処理を施しても低応力側 ではクリープ破断時間及びクリープ抵抗が未使用材の值 にまでは回復しなかつた点について検討する. $750^{\circ} \mathrm{C}$, 応力 $7.5 \mathrm{kgf} / \mathrm{mm}^{2}$ でクリープ破断した再固溶化材の破 面から約 $5 \mathrm{~mm}$ 離れた試料平行部の透過電影組織を Photo. 6 に示す. 粒内における炭化物（大半が $\mathrm{M}_{23} \mathrm{C}_{6}$ と同定された.）の析出密度は未使用材（Photo. 5a)に 比べ低く，また，粒界では， $\sigma$ 相がわずかに観察され， その周囲において, 炭化物の析出密度はさらに低下して いた. 再固溶化材において, クリープ試験中に析出した $\mathrm{M}_{23} \mathrm{C}_{6}$ の粒内における析出密度が，未使用材に比べ低 い理由としては固溶化温度が未使用材に比べ約 $100^{\circ} \mathrm{C}$ 低いため過飽和空孔濃度が低くなり，KEGGらが報告し

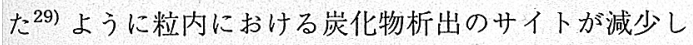
て，析出密度が低下したことが考えられる。また，末使 用材においては確認されなかつた $\sigma$ 相が再固溶化材にお いて観察された理由として，再固溶化時に $\delta$ フフライ トが後者においてわずかに残存していたこと，あるいは， 再固溶化により $\sigma$ 相が消失しても，例えば $\mathrm{Cr}$ の濃度が 十分には均質化されていなかつたことが考えられる.

このことから，使用材に再固溶化熱処理を施してもク リープ破断時間及びクリープ抵抗が未使用材の值にまで は回復しなかつたのは，再固溶化熱処理材の粒界 $\sigma$ 相の 形成が未使用材に比べ非常に速く，使用材と同様 $\sigma$ 相の 周囲において炭化物の消失した軟化領域が形成したこと 及びクリープ中に生じた粒内炭化物の析出密度がより低 いことに起因すると結論される。

また従来，クリープ抵抗に及ぼす $\sigma$ 相析出の効果につ いての議論はほとんど行われていない. 著者らは炭素無
添加の $25 \mathrm{Cr}-20 \mathrm{Ni}$ 鋼に Si を 0.5 及び $1.5 \%$ 添加した 2 種類の鋼について $750^{\circ} \mathrm{C}$, 最長 $10^{4} \mathrm{~h}$ の単純時効を施 し,これら時効材のクリープ試験及び組織観察を行つた 結果， $\sigma$ 相の粒界析出はクリープ抵抗を低下させず，む しろ若干増加させることを明らかにした ${ }^{20)}$.この結果 からも SUS 304 において $\sigma$ 相の析出が材質劣化を招く

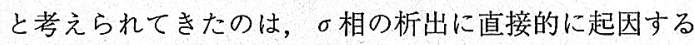
のではなく， $\sigma$ 相の析出によりその周囲ですでに析出し ていた粒内炭化物の析出密度が非常に低下寸ることによ ると結論される。

\section{5. 結}

論

エチレン製造装置のナフサ分解炉において $750^{\circ} \mathrm{C} の$ 単純時効とみなせるほど低い応力で約 $1.2 \times 10^{5} \mathrm{~h}$ 使用 された SUS 304 の機械的特性の劣化の程度を未使用材 と比較することにより調べささらにこの長時間使用材に $1000^{\circ} \mathrm{C}, 30 \mathrm{~h}$ の再固溶化熱処理を施し，機械的性質が どの程度回復するかをも調査して，SUS 304 の材質劣 化を決定する組織因子を検討した結果，以下の結論を得 た.

1. 高温長時間使用した SUS 304 の粒界には塊状の $\sigma$ 相が，粒内には針状の $\sigma$ 相と粒状の $\mathrm{M}_{23} \mathrm{C}_{6}$ が認めら れた.

2. 長時間使用材の短時間引張特性は室温での破断伸 びの低下を除くと，室温及び $750^{\circ} \mathrm{C}$ と末使用材に比 べ大きくは劣化していない，しかし，衝撃值は室温で約 $1 / 6,750^{\circ} \mathrm{C}$ で約 $1 / 3$ にまで激減し，またクリープ破断 時間及びクリープ抵抗はともに半減した。

3. 長時間使用により大きく脆化したシャルピー衝揧 值, 室温での短時間引張試験における破断伸び及びタ リープ破断伸びは再固溶化熱処理を施すことにより，未 使用材と同程度あるいはそれ以上にまで回復する。しか し，長時間の使用により半減あるいはそれ以下にまで劣 化したクリープ破断時間及びクリープ抵抗は再固溶化熱 処理を施すことにより，高応力短時間側では未使用材と 同程度にまで回復するが，低応力長時間側では回復の程 度は小さい。

4. 使用材で大きく劣化し，再固溶化材で未使用材と 同程度にまで回復した衝撃值は粒界に析出した塊状の 相の有無と密接に関連し，これが析出すると割れの発生 及び伝播が容易となつて脆化を招くものと結論した。

5. 使用材で低下し, 再固溶材でも未使用材はどには 回復しなかつたクリープ抵抗はこれまで考えられていた ように，単に粒界 $\sigma$ 相の析出に関連するのではなく，粒 界 $\sigma$ 相の析出に誘発されて生じた $\sigma$ 相の周囲における炭 
化物消失という組織変化に直接的に関連すると結論され る.

終わりに，本研究を行うにあたり有益な御助言をいた だきました東京工業大学工学部松尾 孝助教授に深く感 謝いたします。

\section{文献}

1 ) D. A. Woodford: J. Eng. Mater. Technol., 101 (1979), p. 311

2 ) N. Shin-ya and S. R. Keown: Mater. Sci., 13 (1979), p. 89

3 ) K. R. Williams and B. Wilshire: Mater. Sci., Eng., 28 (1977), p. 289

4 ) $K$. $R$. Williams and B. Wilshire: Mater. Sci. Eng., 38 (1979), p. 199

5 ) C. J. Bolton, B. F. Dyson and K. R. Williams: Mater. Sci. Eng., 46 (1980), p. 231

6 ) L. P. STOTER: J. Mater. Sci., 16 (1981), p. 1039

7 ) R. A. Stevens and P. E. J. FlewitT: Mater. Sci. Eng., 37 (1979), p. 199

8 ) J. M. Leitnaker and J. BentLey: Metall. Trans. A, 8 (1977), p. 1605

9 ) J. H. HoKe and F. EberLE: Trans. ASME, 79 (1957), p. 307

10）条村一弘，松尾 孝，菊池 實，田中良平: 鉄と鋼，72 (1986), p. 474

11）木村一弘，木佐貫哲也，松尾 孝，小松周一，田中良平: 鉄と鋼, 71 (1985), p. 1803

12）松尾 孝, 木佐貫哲也, 田中良平, 小松周一: 鉄と鋼, 70
(1984), p. 565

13）新谷紀雄, 横井 信, 京野純郎, 村田正治, 田中秀雄: 学振 123 委研究報告, 22 (1981), p. 189

14）新谷紀雄, 田中秀雄, 貝瀬正次, 村田正治, 横井 信: 学振 123 委研究報告, 23 (1982), p. 263

15）行俊照夫, 吉川州彦: 学振 123 委研究報告, 10 (1969), p. 229

16）行俊照夫, 吉川州彦: 学振 123 委研究報告, 11 (1970), p. 301

17) 行俊照夫, 吉川州彦: 学振 123 委研究報告, 15 (1974), p. 125

18）太田定雄, 小織 満, 吉田 勉: 学振 123 委研究報告, 16 (1975), p. 197

19）須藤 一, 田賀照男, 内山路夫: 学振 123 委研究報告, 22 (1981), p. 265

20）山口泰広, 田中 勝, 松村智秀, 行方二郎, 近藤義宏: 鉄と鋼, 71 (1985), S618

21） JCPDS カード, No. 5-0708

22) JCPDS カード, No. 14-0407

23) J. BARCIK and B. BrZYCKa: Met. Sci., 17 (1983), p. 256

24）太田定雄, 小織 満, 吉田 勉: 学振 123 委研究報告, 16 (1975), p. 2

25) B. WEISS and R. STICKLER: Metall. Trans., 3 (1972), p. 851

26）西川 廣, 松尾 孝, 篠田隆之, 田中良平: 鉄と鋼, 63 (1977), S 580

27）張 俊善, 竹山雅夫, 松尾 孝, 菊池 實, 田中良平: 鉄と鋼，73 (1987), p. 183

28）小林俊郎: 日本金属学会会報, 12 (1973), p. 546

29) G. R. KEGG, J. M. SilcoCK and D. R. F. WeST: Met. Sci., 8 (1974), p. 337 